\section{Extraction, Separation, and Purification of Blueberry Anthocyanin Using Ethyl Alcohol}

\author{
Z. Gao* \\ College of Food Science and Technology, Hebei Agricultural University, \\ Baoding, Hebei, 071 000, P.R. China
}

DOI: $10.15255 /$ KUI.2017.041 KUI-47/2017

Preliminary communication Received September 25, 2017 Accepted October 20, 2017

This work is licensed under a Creative Commons Attribution 4.0

\begin{abstract}
| Abstract
Blueberry contains many substances that are important to the human body and can prevent cardiovascular diseases, protect the retina, and soften blood vessels. Anthocyanin, which is extracted from blueberry, can activate the retina, strengthen vision, reduce serum cholesterol, triglyceride and high-density lipoprotein, and protect cell nucleus tissues from radical oxidation; hence, blueberry is of importance to scientists from different countries. In this study, anthocyanin was extracted and separated from blueberry using ethyl alcohol to investigate the effects of factors, such as ethyl alcohol volume ratio on anthocyanin extraction and separation technologies. The extracting solution was then purified using the macroreticular resin purification method to investigate the effects of ethyl alcohol concentration and eluent dosage on anthocyanin extraction during purification. The research results demonstrated that $60 \%$ ethyl alcohol volume fraction, $1: 10$ mass ratio of solid to liquid, and $60{ }^{\circ} \mathrm{C}$ ultrasonic temperature were the best conditions for anthocyanin extraction. The best purification conditions were $95 \%$ ethyl alcohol, which had been acidized by $0.3 \%$ hydrochloric acid and $70 \mathrm{ml}$ of eluent. This work provides a reference for the application of ethyl alcohol in anthocyanin extraction.
\end{abstract}

$\|$ Keywords

Blueberry, anthocyanin, extraction, separation, purification

\section{Introduction}

The blueberry, a blue fruit, belongs to Ericaceae, and it is favoured by people because of its sweet and sour taste, and a large amount of nutritional substances. It is rich in anthocyanin, which is important to the human body and can effectively protect retinal cells and prevent cardiovascular diseases. ${ }^{1}$ Anthocyanin, as a water-soluble natural food colouring, can be dissolved by polar solvents, such as methyl alcohol and ethyl alcohol, as well as affected by elements, such as sunlight and temperature. Moreover, it has higher safety compared to the synthetic pigment. 2,3,4 Because of the antioxidant function of anthocyanin, which is 50 times that of vitamin E, it can induce proper crosslinking of collagen, eliminate free radicals, and protect the skin. ${ }^{5}$ In addition, it can reduce serum cholesterol, triglyceride, and high-density lipoprotein, enhance low density lipoprotein, inhibit atherosclerosis, regulate blood fat, and prevent cardiovascular diseases and high blood pressure. ${ }^{6}$ Blueberry anthocyanin has received much attention because it is edible and contains rich nutritional values.

J. Chen et al. investigated the protective effect and antioxidation mechanism of blueberry anthocyanin extractive in vivo and in vitro using acute CC14-induced mouse hepatic injury model, and found that blueberry anthocyanin extractive could effectively prevent acute hepatic injury. ${ }^{7}$ Y. Liu et al. investigated the protective effect of blueberry

* Zhe Gao, Doctoral candidate

e-mail: gaozhe1979@outlook.com anthocyanin on retinal pigment epithelium through establishing in vitro cell models of replicative senescence and photo-induced injury, and found that blueberry anthocyanin could inhibit the aging of retinal pigment epithelium and protect the cells from photoinduced injury. ${ }^{8}$ Anthocyanin can promote the regeneration of rhodopsin and blood circulation, thereby preventing high myopia and improving vision.

J. Y. Gou et al. found that at least one of the miR156 targets, SPL9, could directly inhibit anthocyanin biosynthesis and reduce the accumulation of anthocyanin through destabilization of a MYB-bHLH-WD40 transcriptional activation complex. ${ }^{9}$ Their research results revealed the direct connection between the transition to flowering and secondary metabolism, and offered a potential target for the processing of anthocyanin and flavonol content in plants. In the study of $A$. Patras et al., ${ }^{10}$ they mentioned some matters about anthocyanin degradation in thermal processing, and gave a summary of the mechanisms of anthocyanin degradation based on the current dynamics conclusions. The current anthocyanin extraction methods include solvent extraction method, ultrasonic extraction, etc. However, the former has low efficiency and the latter costs too much.

In this study, blueberry anthocyanin was extracted using ultrasonic-assisted solution, anthocyanin was purified with macroreticular resin purification, and the factors influencing the extraction, separation, and purification of anthocyanin were analysed, aiming to provide a reference for the extraction, separation, and purification of blueberry anthocyanin. 


\section{Experimental}

\subsection{Materials}

The used blueberries were picked from the blueberry planting base in Shijiazhuang, Hebei, China.

\subsection{Reagents and equipment}

Reagents included AB-8 macroporous resin, vanillic aldehyde (chemically pure), concentrated hydrochloric acid, methyl alcohol (analytically pure), distilled water, citric acid, sodium citrate, hydrochloric acid (36.0-38.0\%), ethyl alcohol (95\%) and ethyl acetate. Equipment included a beater, KQ5200DE numerical control ultrasonic cleaner, RE-52AA rotary evaporator, 722 visible spectrophotometer, and 80-1 medical centrifuge.

\subsection{Blueberry anthocyanin extraction and purification techniques}

There were three blueberry anthocyanin extraction techniques, i.e. solvent extraction, supercritical extraction, and ultrasonic-assisted solvent extraction. Ultrasonic wave can increase the dissolution of anthocyanin and promote the extraction and separation of anthocyanin through inducing a chemical combination between blueberry and solvent. ${ }^{11}$ Hence, ultrasonic-assisted solvent extraction was adopted in this study.

There were also three anthocyanin purification techniques, i.e. resin purification, high-speed counter-current chromatography and high performance liquid chromatography. Resin purification was used in this study. The specific operating procedures were as follows.

\subsection{Extraction and separation of blueberry anthocyanin}

Twenty grams of blueberry were taken and made into fruit pulp using a beater. Ultrasonic extraction was performed using $0.3 \%$ hydrochloric acid and $95 \%$ ethyl alcohol at $40{ }^{\circ} \mathrm{C}$ for $30 \mathrm{~min}$. After four extractions at a solid-liquid ratio of $1 \mathrm{~g}: 6 \mathrm{ml}$, extraction filtration was performed and the filtrate was collected. The red viscous fluid was then obtained after decompression at $40{ }^{\circ} \mathrm{C}$.

\subsection{Purification of blueberry anthocyanin}

Firstly, AB-8 macroporous resin was immersed in ethyl alcohol for 24 hours. After it was fully swelled, it was washed until there was no turbidity. Then it was washed by deionised water until there was no smell of ethyl alcohol. Resin liquid was removed. Thirty millilitres of concentrated solution, $60 \mathrm{ml}$ of distilled water and $60 \mathrm{ml}$ of ethyl acetate were added for five extractions. The ethyl acetate was then removed by decompression at $40{ }^{\circ} \mathrm{C}$. Sixteen grams of AB-8 macroporous resin, which had been preprocessed, were transferred to chromatographic column, and $30 \mathrm{ml}$ of the concentrated solution obtained above was loaded. After sample loading, it was absorbed by AB- 8 macroporous resin for three hours. The impurities, such as protein, were then washed away with $50 \mathrm{ml}$ of distilled water. Anthocyanin, which adhered to the resin, was eluted with $140 \mathrm{ml}$ of $0.3 \%$ hydrochloric acid and $95 \%$ ethyl alcohol. Finally, viscous fluid was obtained after decompression at $40{ }^{\circ} \mathrm{C}$.

\subsection{Calculation of anthocyanin content}

Anthocyanin content:

$$
\gamma=(A \cdot M \cdot F \cdot V) /(m \cdot \varepsilon \cdot l)
$$

where $\gamma$ stands for the mass concentration of anthocyanin, $A$ is absorbance, ${ }^{12} M$ is the molar mass of cyanidin 3-O-glucoside, $449.2 \mathrm{~g} \mathrm{~mol}^{-1}, F$ is the dilution ratio of blueberry fruit pulp, $V$ is the volume of extracting solution, $m$ is the mass of blueberry, $\varepsilon$ is attenuation coefficient, ${ }^{13}$ $29600 \mathrm{I} \mathrm{mol}^{-1} \mathrm{~cm}^{-1}$, and $/$ is the width of cuvette, $1 \mathrm{~cm}$.

\subsection{Calculation of anthocyanin purity}

The mass of anthocyanin in the solution was calculated using Eq. (1). The purity of anthocyanin was then calculated using the following formula: purity = mass of anthocyanin in product/total mass of product.

\section{Results and discussion}

\subsection{Analysis of investigation factors involved in extraction and separation of anthocyanin}

\subsubsection{Effects of volume fraction of ethyl alcohol}

Twenty-four grams of blueberry were taken and made into fruit pulp. Ultrasonic extraction was then carried out at $40{ }^{\circ} \mathrm{C}$ by adding $40 \%, 50 \%, 60 \%, 70 \%$, and $90 \%$ ethyl alcohol, respectively, in a ratio of $1: 6.6$. After that, extraction filtration was performed and the filtrate was separated; the absorbance of anthocyanin was detected. The content of anthocyanin was calculated using Eq. (1). The experimental results are shown in Fig. 1.

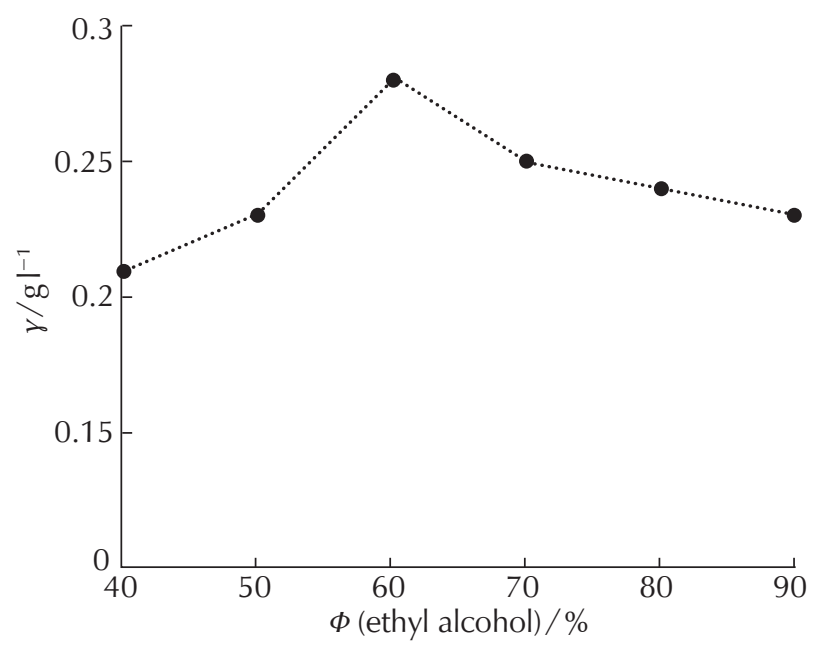

Fig. 1 - Effects of ethyl alcohol concentration on the mass concentration of anthocyanin 
Fig. 1 shows that the content of anthocyanin increased with the increase in ethyl alcohol volume fraction $(\Phi)$ when ethyl alcohol volume fraction was between $40 \%$ and $60 \%$, it reached the peak when it was $60 \%$, and decreased with the increase in ethyl alcohol volume fraction when it was between $60 \%$ and $90 \%$. Ethyl alcohol with excessively high volume fraction damaged the internal structure of anthocyanin; hence, ethyl alcohol with a volume fraction of $60 \%$ was the best in the extraction of blueberry anthocyanin. The difference in anthocyanin content using $60 \%$ ethyl alcohol and ethyl alcohol with the other volume ratio had statistical significance $(p<0.05)$.

\subsubsection{Effects of mass ratio of solid to liquid}

Ethyl alcohol with a volume fraction of $60 \%$ was used to extract blueberry anthocyanin at $40{ }^{\circ} \mathrm{C}$ for $30 \mathrm{~min}$. The content of anthocyanin was detected when mass ratio of solid to liquid was $1: 4,1: 6,1: 8,1: 10,1: 12$, and $1: 14$, respectively.

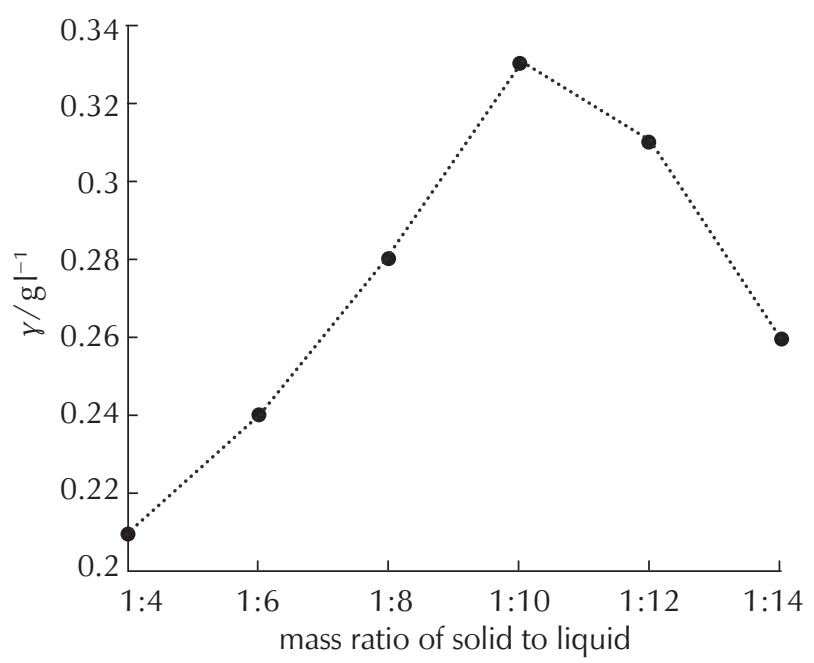

Fig. 2 - Effects of mass ratio of solid to liquid on the mass concentration of anthocyanin

As shown in Fig. 2, the content of anthocyanin increased with the decrease in mass ratio of solid to liquid when mass ratio of solid to liquid was between $1: 4$ and $1: 10$. When mass ratio of solid to liquid was $1: 10$, the content of anthocyanin extracted was the highest; when mass ratio of solid to liquid was lower than $1: 10$, the content of anthocyanin decreased with the decrease in mass ratio of solid to liquid. Therefore, the content of anthocyanin was the highest when mass ratio of solid to liquid was $1: 10$.

\subsubsection{Effects of extraction temperature}

Twenty-four grams of blueberry were taken and made into fruit pulp and evenly divided into 6 pieces. Ethyl alcohol at a volume fraction of $60 \%$ was then added in a ratio of $1: 6.6$, and the anthocyanin was extracted by ultrasound at $15{ }^{\circ} \mathrm{C}, 30{ }^{\circ} \mathrm{C}, 45{ }^{\circ} \mathrm{C}, 60 \%, 75 \%$, and $90 \%$, respectively, for $30 \mathrm{~min}$. The absorbance of the concentrated solution, which was obtained by extraction filtration, was detected. The extraction content of anthocyanin was calculated using Eq. (1), and the results are shown in Fig. 3.

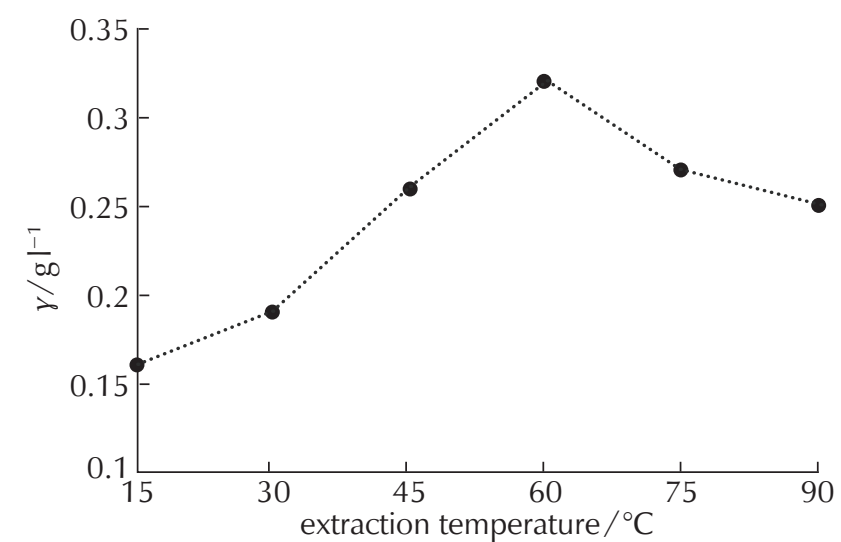

Fig. 3 - Relationship between extraction temperature and the mass concentration of anthocyanin

As shown in Fig. 3, the content of anthocyanin increased firstly, and then decreased with the increase in temperature. When the extraction temperature was $60{ }^{\circ} \mathrm{C}$, the content of anthocyanin was the highest, and its difference with the content using the other temperatures had statistical significance $(p<0.05)$. Hence, it could be concluded that $60{ }^{\circ} \mathrm{C}$ was the best temperature for the extraction and separation of blueberry anthocyanin.

\subsection{Analysis of investigation factors involved in anthocyanin purification}

\subsubsection{Effects of volume fraction of ethyl alcohol}

As anthocyanin is a polar compound, regulating the volume fraction of ethyl alcohol can accelerate the dissociation and release of anthocyanin, greatly affecting the purification speed of anthocyanin in purification technique.

Thirty millilitres of concentrated solution, the impurities of which had been removed using ethyl acetate, were taken and loaded into a $16 \mathrm{~g} \mathrm{AB}-8$ macroporous resin chromatographic column. The impurities, such as protein, were then washed away with $50 \mathrm{ml}$ of distilled water; after that, $0.3 \%$ hydrochloric acid and ethyl alcohol at volume fraction of $40 \%, 50 \%, 60 \%, 70 \%, 80 \%$, and $95 \%$ were added to elute the volume fraction of ethyl alcohol. 


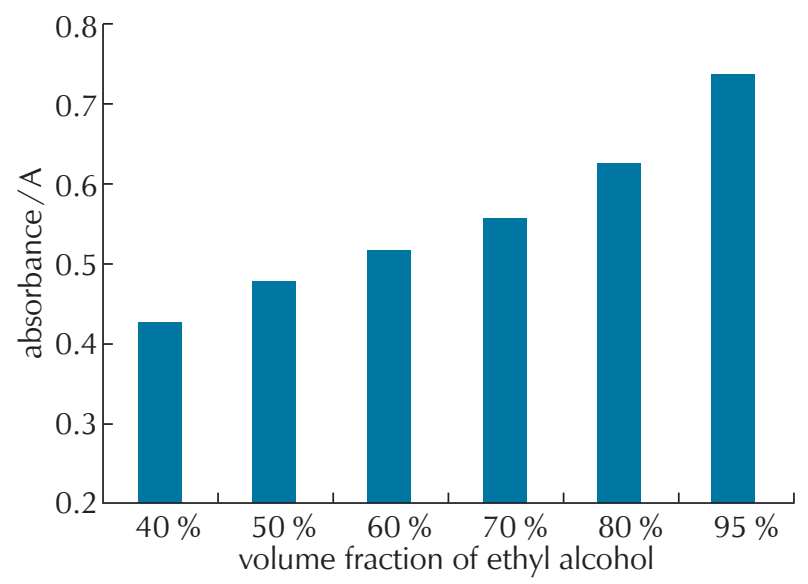

Fig. 4 - Effects of the volume fraction of ethyl alcohol on purification of anthocyanin

As shown in Fig. 4, the absorbance and the content of anthocyanin increased with the increase of ethyl alcohol volume fraction. When the volume ratio of ethyl alcohol was $95 \%$, the absorbance was the highest, and the difference with that using ethyl alcohol with the other volume fractions had statistical significance $(p<0.05)$; the content of anthocyanin was also the highest and the elution efficiency was the best. Therefore, $95 \%$ was the best volume fraction for ethyl alcohol in the test.

\subsubsection{Effects of eluent dose}

It was concluded from the above experiments that $95 \%$ ethyl alcohol, which was acidized with $0.3 \%$ hydrochloric acid, was the best eluent in purification of anthocyanin. Procedures of the test on the dose of eluent in purification of anthocyanin were as follows. Firstly, $30 \mathrm{ml}$ of concentrated solution, the impurities of which had been removed by ethyl acetate, were taken and then loaded into a 16gAB-8 macroporous resin chromatographic column. After impurities were washed with $50 \mathrm{ml}$ of distilled water, $95 \%$ ethyl alcohol, which had been acidized with $0.3 \%$ hydrochloric acid, was added to elute anthocyanin. Twenty millilitres of eluent were then added, and the absorbance tested and recorded. The dosage of eluent increased gradually, $10 \mathrm{ml}$ each time. The results were recorded as follows.

As shown in Fig. 5, the absorbance decreased with the increase in eluent dose, rapidly decreased when the dose of eluent was between $20 \mathrm{ml}$ and $70 \mathrm{ml}$, recovered after $70 \mathrm{ml}$, and finally decreased slowly. After comprehensive consideration, $70 \mathrm{ml}$ was found to be the best dose.

In conclusion, the amount of blueberry anthocyanin extracted was the highest when the volume fraction of ethyl alcohol was $60 \%$, the mass ratio of solid to liquid was $1: 10$, and ultrasonic temperature was $60^{\circ} \mathrm{C}$. In the purification of anthocyanin, anthocyanin had the highest absorbance and purity when $70 \mathrm{ml}$ of $95 \%$ ethyl alcohol, which was acidized with $0.3 \%$ hydrochloric acid, were used for elution.

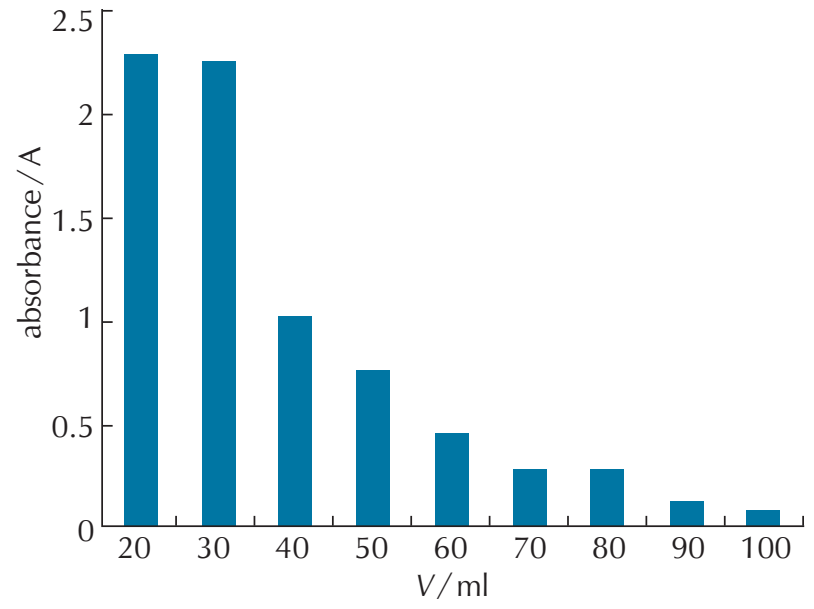

Fig. 5 - Effects of dose of eluent

\section{Conclusion}

In this study, blueberry anthocyanin was extracted and separated using ethyl alcohol as the solvent. The effects of ethyl alcohol volume fraction, mass ratio of solid to liquid, and extraction temperature on the content of blueberry anthocyanin were investigated through the experiments. Moreover, the extracted anthocyanin was purified by macroporous resin method. It was found that $95 \%$ ethyl alcohol, which had been acidized with $0.3 \%$ hydrochloric acid and $70 \mathrm{ml}$ of eluent, achieved the best purification efficiency. This study provides some references for the extraction, separation, and purification of blueberry anthocyanin.

\section{List of abbreviations and symbols}

A - absorbance

$F \quad$ - dilution ratio of blueberry fruit pulp, $\mathrm{g} \mathrm{ml}^{-1}$

I - width of cuvette, $\mathrm{cm}$

$m$ - mass of blueberry, $g$

$M$ - molar mass of cyanidin 3-O-glucoside, $\mathrm{g} \mathrm{mol}^{-1}$

$\checkmark$ - volume of extracting solution, $\mathrm{ml}$

$\gamma$ - mass concentration

$\varepsilon \quad-$ attenuation coefficient, $\mathrm{I} \mathrm{mol}^{-1} \mathrm{~cm}^{-1}$

$\Phi$ - volume fraction, $\%$

\section{References}

\section{Literatura}

1. M. A. Wilson, B. Shukitt-Hale, W. Kalt, D. K. Ingram, J. A. Joseph, C. A. Wolkow, Blueberry polyphenols increase lifespan and thermotolerance in Caenorhabditis elegans, Aging Cell 5 (1) (2006) 59-68, doi: https://doi. org/10.1111/j.1474-9726.2006.00192.x.

2. A. Mendelová, L. Mendel, M. Fikselová, P. Czako, Evaluation of anthocyanin changes in blueberries and in 
blueberry jam after the processing and storage, Potrav: Sci. J. Food. Ind. 7 (1) (2013) 130-135, doi: https://doi. org/10.5219/293.

3. Q. You, B. Wang, F. Chen, Z. Huang, X. Wang, P. G. Luo, Comparison of anthocyanins and phenolics in organically and conventionally grown blueberries in selected cultivars, Food Chem. 125 (1) (2011) 201-208, doi: https:// doi.org/10.1016/j.foodchem.2010.08.063.

4. A. Faria, D. Pestana, D. Teixeira, V. de Freitas, N. Mateus, C. Calhau, Blueberry anthocyanins and pyruvic acid adducts: anticancer properties in breast cancer cell lines, Phytoth. Res. 24 (12) (2010) 1862-1869, doi: https://doi. org/10.1002/ptr.3213.

5. S. Hogan, H. Chung, L. Zhang, J. R. Li, Y. W. Lee, Y. M. Dai, K. Q. Zhou, Antiproliferative and antioxidant properties of anthocyanin-rich extract from açai, Food Chem. 118 (2) (2010) 208-214, doi: https://doi.org/10.1016/j.foodchem.2009.04.099.

6. S. M. Bornsek, L. Ziberna, T. Polak, A. Vanzo, N. P. Ulrih, V. Abram, F. Tramer, S. Passamonti, Bilberry and blueberry anthocyanins act as powerful intracellular antioxidants in mammalian cells, Food Chem. 134 (4) (2012) 1878-1884, doi: https://doi.org/10.1016/j.foodchem.2012.03.092.

7. J. Chen, H. N. Sun, A. D. Sun, Q. H. Lin, Y. Wang, X. Y. Tao, Studies of the protective effect and antioxidant mechanism of blueberry anthocyanins in a CC14-induced liver injury model in mice, Food Agricult. Immun. 3 (4) (2012) 352-362, doi: https://doi.org/10.1080/09540105.2011.63 4378.

8. Y. Liu, X. Song, D. Zhang, F. Zhou, D. Wang, Y. Wei, F. Y. Gao, L. Y. Xie, G. Jia, W. Wu, B. P. Ji, Blueberry anthocyanins: protection against ageing and light-induced damage in retinal pigment epithelial cells, Br. J. Nutrit. 108 (1) (2012) 16-27, doi: https://doi.org/10.1017/S000711451100523X.

9. J. Y. Gou, F. F. Felippes, C. J. Liu, D. Weigel, J. W. Qang, Negative regulation of anthocyanin biosynthesis in Arabidopsis by a miR156-targeted SPL transcription factor, Plant Cell 23 (4) (2011) 1512, doi: https://doi.org/10.1105/ tpc.111.084525.

10. A. Patras, N. P. Brunton, C. O'Donnell, B. K. Tiwari, Effect of thermal processing on anthocyanin stability in foods; mechanisms and kinetics of degradation, Trends Food Sci. Tech. 21 (1) (2010) 3-11, doi: https://doi.org/10.1016/j. tifs.2009.07.004.

11. E. K. Kopp, H. Fromme, W. Völkel, Analysis of common and emerging brominated flame retardants in house dust using ultrasonic assisted solvent extraction and online sample preparation via column switching with liquid chromatography-mass spectrometry, J. Chrom. A 1241(11) (2012) 28-36, doi: https://doi.org/10.1016/j. chroma.2012.04.022.

12. J. T. Robinson, S. M. Tabakman, Y. Y. Liang, H. L. Wang, H. S. Casalongue, D. Vinh, H. J. Dai, Ultrasmall Reduced Graphene Oxide with High Near-Infrared Absorbance for Photothermal Therapy, J. Am. Chem. Soc. 133 (17) (2011) 6825-6831, doi: https://doi.org/10.1021/ja2010175.

13. D. Kuang, C. Klein, S. Ito, J. E. Moser, R. Humphry-Baker, N. Evans, F. Duriaux, C. Grätzel, S. M. Zakeeruddin, M. Graetzel, High-Efficiency and Stable Mesoscopic Dye-Sensitized Solar Cells Based on a High Molar Extinction Coefficient Ruthenium Sensitizer and Nonvolatile Electrolyte, Adv. Mater. 19 (8) (2010) 1133-1137, doi: https://doi.org/10.1002/adma.200602172.

\section{SAŽETAK \\ Ekstrakcija, odvajanje i pročišćavanje antocijanina borovnice etanolom \\ Zhe Gao}

Borovnica sadrži niz tvari koje su važne za ljudsko tijelo te mogu spriječiti kardiovaskularne bolesti, zaštititi mrežnicu i poboljšati stanje krvnih žila. Antocijanin, ekstrahiran iz borovnice, može aktivirati mrežnicu, ojačati vid, smanjiti serumski kolesterol, triglicerid i lipoprotein visoke gustoće te zaštititi tkivo stanica od radikalske oksidacije; dakle, borovnica je važna znanstvenicima diljem svijeta. Kako bi se istražili učinci čimbenika kao što je volumni omjer etilnog alkohola pri ekstrakciji antocijanina i tehnologija odvajanja, antocijanin je u ovoj studiji ekstrahiran i odvojen iz borovnice etanolom. Otopina za ekstrakciju je zatim pročišćena makroretikularnom smolom radi ispitivanja učinaka koncentracije etanola i doziranja eluenta na ekstrakciju antocijanina tijekom čišćenja. Rezultati istraživanja pokazali su da su volumni udjel etanola od $60 \%$, maseni omjer čvrste tvari i tekućine od $1: 10 \mathrm{i}$ ultrazvučna kupelj pri $60^{\circ} \mathrm{C}$ najbolji uvjeti za ekstrakciju antocijanina. Najbolji uvjeti za pročišćavanje bili su 95 \% etilnog alkohola koji je bio zakiseljen s 0,3 \% klorovodične kiseline i $70 \mathrm{ml}$ eluenta. Ovaj rad daje referenciju za primjenu etanola u ekstrakciji antocijanina.

Ključne riječi

Borovnica, antocijanin, ekstrakcija, odvajanje, pročišćavanje

College of Food Science and Technology,

Hebei Agricultural University,

Baoding, Hebei 071 000, Kina

Prethodno priopćenje

Prispjelo 25. rujna 2017.

Prihvaćeno 20. listopada 2017. 